\title{
Anti-ErbB3 Monoclonal Antibody AV-203
}

National Cancer Institute

\section{Source}

National Cancer Institute. Anti-ErbB3 Monoclonal Antibody AV-203. NCI Thesaurus. Code C102535.

A humanized monoclonal antibody (MoAb) directed ag ainst the human receptor tyrosineprotein kinase ErbB-3 (HER3) with potential antineoplastic activity. Anti-ErbB3 MoAb AV203 binds to and inhibits both lig and neuregulin-1 (NRG-1)-dependent and ligandindependent ErbB3 activation, which may result in inhibition of ErbB3-dependent PI3K/Akt signaling and may lead to inhibition of cellular proliferation and differentiation. ErbB3, a member of the epidermal growth factor receptor (EGFR) family, is frequently overexpressed in solid tumors and its overexpression generally correlates with poor prognosis and tumor resistance; it has no active kinase domain itself but is activated through heterodimerization with other members of the EGFR receptor family that do. 